\title{
9
}

\section{The Batanes Nephrite Artefacts}

\author{
Hsiao-chun Hung and Yoshiyuki lizuka
}

Nephrite (jade) ornaments, especially ear-ornaments, are among the most attractive artefacts in Southeast Asian archaeology. As Loofs-Wissowa stated (1980-81: 57): "Ear-ornaments in general seem to have played, and are still playing in some societies, a greater role in Southeast Asia and parts of South Asia than almost anywhere else in the world...." Because of the beautifully wrought shapes and enchanting translucent colours of nephrite or jadeitite ornaments, generations of archaeologists have asked who made them, during which time period, with what kind of manufacturing process, using which trading networks, and for what purpose.

\section{The study of nephrite in Philippine archaeology}

In the Philippines, several thousand tools of a white variety of nephrite, especially adzes and chisels, were discovered during the 1930s and 1940s by H. Otley Beyer in Batangas, Rizal and Laguna Provinces in southwestern Luzon (Beyer 1948: 44-71). During the 1960s and 1970s, Robert Fox (1970: 127-135) excavated about 350 green nephrite ornaments, including lingling-o earrings, bracelets and beads, from sites on Palawan Island, particularly from the Tabon Cave Complex on Lipuun Point. Besides these findings, more nephrite artefacts have been found in other parts of the Philippines during the past decade, especially from the Batanes Islands, as described here.

Where were the geological sources for these nephrite artefacts found in the Philippines? $\mathrm{H}$. Otley Beyer (1947: 249) noted: "Equally intriguing is the origin of the Batangas nephrite. The great quantity of artefacts found led us to seek diligently for some possible local source of the material, but the results so far have been wholly negative...". Over 20 years later, Robert B. Fox (1970: 131) commented on the same issue: “... there is no question that nephrite was worked extensively ... in the Philippines, notably in Batangas Province where the writer believes a local but still undiscovered source of nephrite was known and worked...”.

Seeking nephrite sources has been a major preoccupation in Philippine archaeology, important not only for understanding these objects of art but also for studies of cultural interaction, trade, and the development of craft specialisation. Since the 1940s, archaeologists in Southeast Asia have noted the widespread occurrence of nephrite ornaments with similar characteristics and have postulated various opinions about their possible dispersal histories. Kano Tadao (1946: 233) was the first to discern at least four types of penannular nephrite earring with circumferential projections in Southeast Asia. He believed that they originated in northern Vietnam, whence 
they spread northwards to Hong Kong and Taiwan. He believed as well that they could have reached Taiwan via northern Luzon (in the case of his types 2, 3 and 4) (see Hung et al. 2006, Fig. 20.1). In these early studies, researchers explored cultural contacts and exchange only from a typological perspective. However, the data that may be derived from such an approach will be extremely limited without knowing the sources of the raw materials.

\section{The past decade of research}

Because nephrite is a rare mono-mineralic rock, formed only under specific geological conditions, it is highly amenable to geochemical compositional analysis for fingerprinting the sources used for those artefacts that eventually were transported to distant locations. From geological information, there are about 120 known nephrite deposits in the world, distributed in roughly 20 countries (Harlow and Sorensen 2005). In East Asia, nephrite deposits are located in Siberia, Mainland China, Korea, Japan, and at Fengtian in eastern Taiwan. So far, no green nephrite sources have been reported from Island Southeast Asia, although there are separate white nephrite sources that exhibit different mineralogy in southern Luzon and probably Vietnam (Hung et al. 2007). Therefore, the geological source(s) of the green nephrite artefacts found in the Philippines and other Southeast Asian sites present questions of great interest.

Recent developments in archaeology, in partnership with earth sciences, have provided us with a uniquely informative way to combine the typological comparative methods of archaeology with applications of mineral and chemical analysis, in order to source nephrite artefacts in the Philippines and other Southeast Asian countries. Since 2000, a number of sourcing techniques have been applied by various colleagues working in collaboration with us. Chih-ming Wang Lee has performed X-ray diffraction (XRD) in the Department of Geology, National Taiwan University, in Taipei. Stable oxygen isotope analysis has been undertaken by Tzeng-fu Yui of the Institute of Earth Sciences, Academia Sinica, also in Taipei. Most recently, Yoshiyuki Iizuka has developed an approach using electron probe micro-analysis (EPMA) and low vacuum type scanning electron microscopy (LV-SEM), equipped with energy dispersive X-ray spectrometry (EDS), in the Institute of Earth Sciences at Academia Sinica. The technicalities behind these techniques have been described in our other publications (Hung et al. 2004; Iizuka and Hung 2005; Iizuka et al. 2005, 2007; Hung et al. 2007).

Between 2003 and 2004, our studies began to focus mostly on the Philippines, primarily working with collections in the National Museum of the Philippines in Manila. In 2004, Peter Bellwood and Eusebio Dizon discovered the Anaro nephrite workshop on Itbayat Island in Batanes, which has provided the bulk of the artefacts described here. In this chapter, we review all discoveries and sourcing results of nephrite and jade-like remains in the Batanes Islands, finishing with a broader cultural interpretation of the Batanes nephrite materials in the context of Southeast Asian archaeology.

\section{Nephrite and other jade-like artefacts from Batanes}

Since 2004, excavations at Anaro (Itbayat Island) have recovered many drilled-out disc-shaped and cylindrical cores, pelta-shaped pieces, and grooved-and-cut nephrite debris, all strongly indicative of the former existence of a nephrite workshop on the site. The Anaro chronology is discussed in more detail in chapters 2 and 5 , where it was noted that the majority of the nephrite pieces belonged to Batanes Phase 2, subphase $2 \mathrm{~b}$, dating between $500 \mathrm{BC}$ and the early centuries $\mathrm{AD}$. They were found mostly in association with Anaro circle-stamped type 1 pottery sherds.

So far, most of the nephrite and jade-like cut fragments and artefacts have been discovered predominately as surface finds from the Anaro workshop. Currently, there are 58 samples from 
Anaro, two from Savidug, and one from Sunget. After testing by Yoshiyuki Iizuka of all of the pieces from the total project, each has been confirmed as falling within the geochemical ranges of Fengtian nephrite from eastern Taiwan, except for one piece of mica and another two of quartz schist (Fig. 9.1).
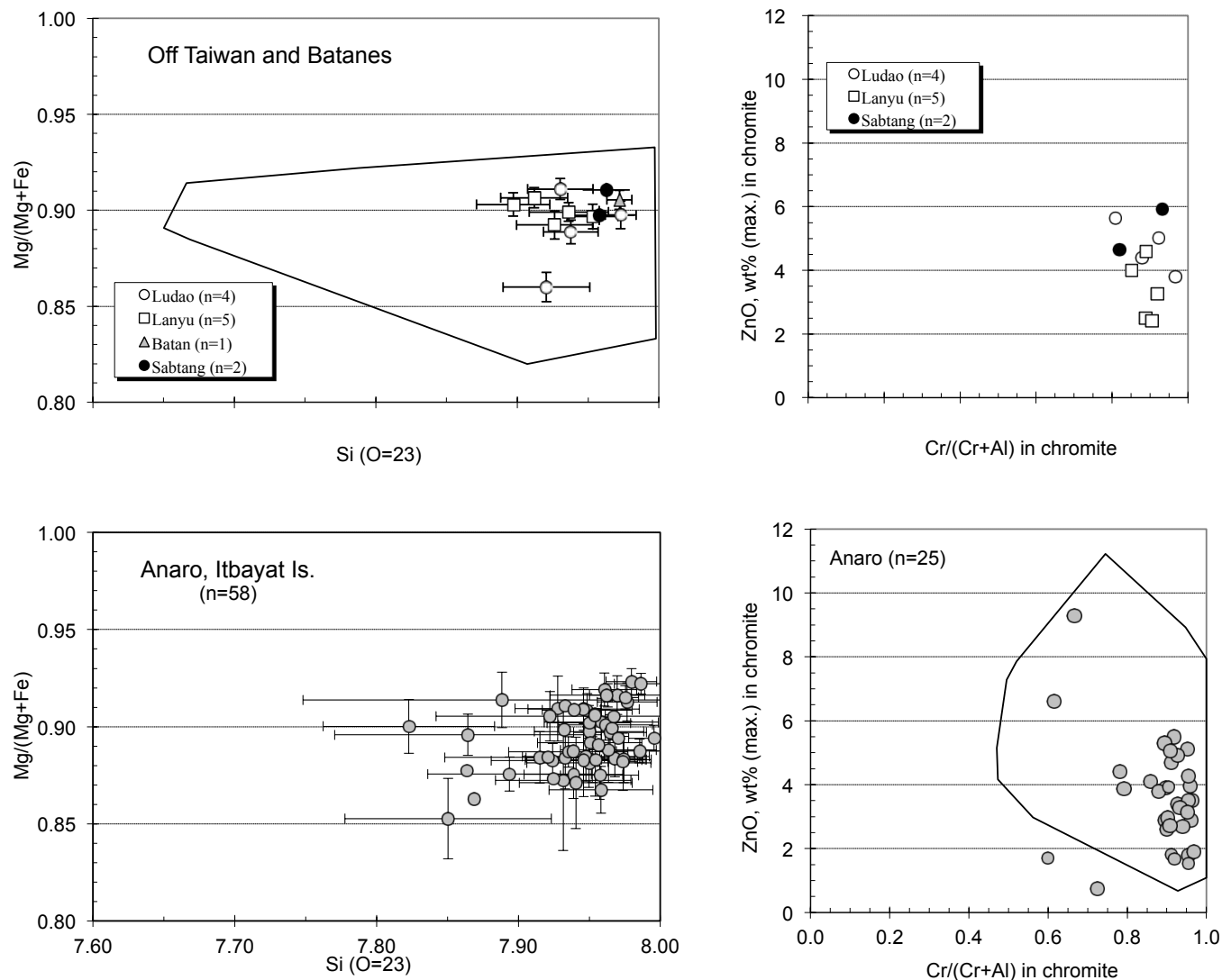

Figure 9.1. Left side: Chemical compositions of nephrite artefact matrices. The X-and $\mathrm{Y}$-axes represent $\mathrm{Si}$ (atoms per formula unit) and $\mathrm{Mg} /(\mathrm{Mg}+\mathrm{Fe})$ ratios, respectively, of (a-amphibole $\mathrm{Ca} 2(\mathrm{Mg}, \mathrm{Fe}) 5(\mathrm{Si} 8022)(\mathrm{OH}) 2$. The chemical boundary between tremolite and actinolite is $0.90 \mathrm{in}$ the $\mathrm{Mg} /(\mathrm{Mg}+\mathrm{Fe}$ ) ratio (Leake et al. 1997). The enclosed areas in each plot contain the chemical compositions of source nephrite samples from the Fengtian mine area in eastern Taiwan (8-hand specimens and 262 analysis points) and a nearby riverbed (9-hand specimens and 385 analysis points) (after lizuka and Hung 2005). n: numbers of analysis spots by the non-invasive LVSEM-EDS technique. Right side: Chemical compositions of zinc-bearing chromite ([Mg, $\mathrm{Fe}, \mathrm{Zn}][\mathrm{Al}, \mathrm{Cr}] 204)$ inclusions in the surfaces of nephrite artefacts, analysed by the noninvasive LVSEM-EDS technique. Symbols represent the value for zinc oxide ( $\mathrm{ZnO}$ in wt \%) and the $\mathrm{Cr} /(\mathrm{Cr}+\mathrm{Al})$ ratio for each artefact. Because the chromite in Fengtian nephrite bears significant amounts of zinc (2 to $11 \mathrm{wt} \%$ in Zn0) (lizuka and Hung 2005) in comparison with the other possible green nephrite (actinolite/tremolite) sources tested (Chara Jelgra, Siberia and Nanshan, Gansu), the Zn content provides a good clue for the identification of Fengtian nephrite. Enclosed areas contain the chemical compositions of Fengtian nephrite samples.

Source: Yoshiyuki lizuka.

\section{Batan Island}

A nephrite adze (Fig. 9.2 A) from Sunget was first reported by Koomoto (1983: 61; Fig. 25: 48) as a small miniature stone axe. We examined this artefact in 2006, and confirmed it as an adze of Fengtian (Taiwan) nephrite, of a type very common during the Taiwan Neolithic. In Taiwan itself, nephrite adzes first appeared in the Early Neolithic (c.3000 BC) and were made and used 
extensively through the Late Neolithic (Hung 2004: 58), even continuing into the Iron Age. As discussed in chapters 3 and 5, Sunget is dated between 1200 and 800 BC, contemporary with the Late Neolithic in Taiwan.

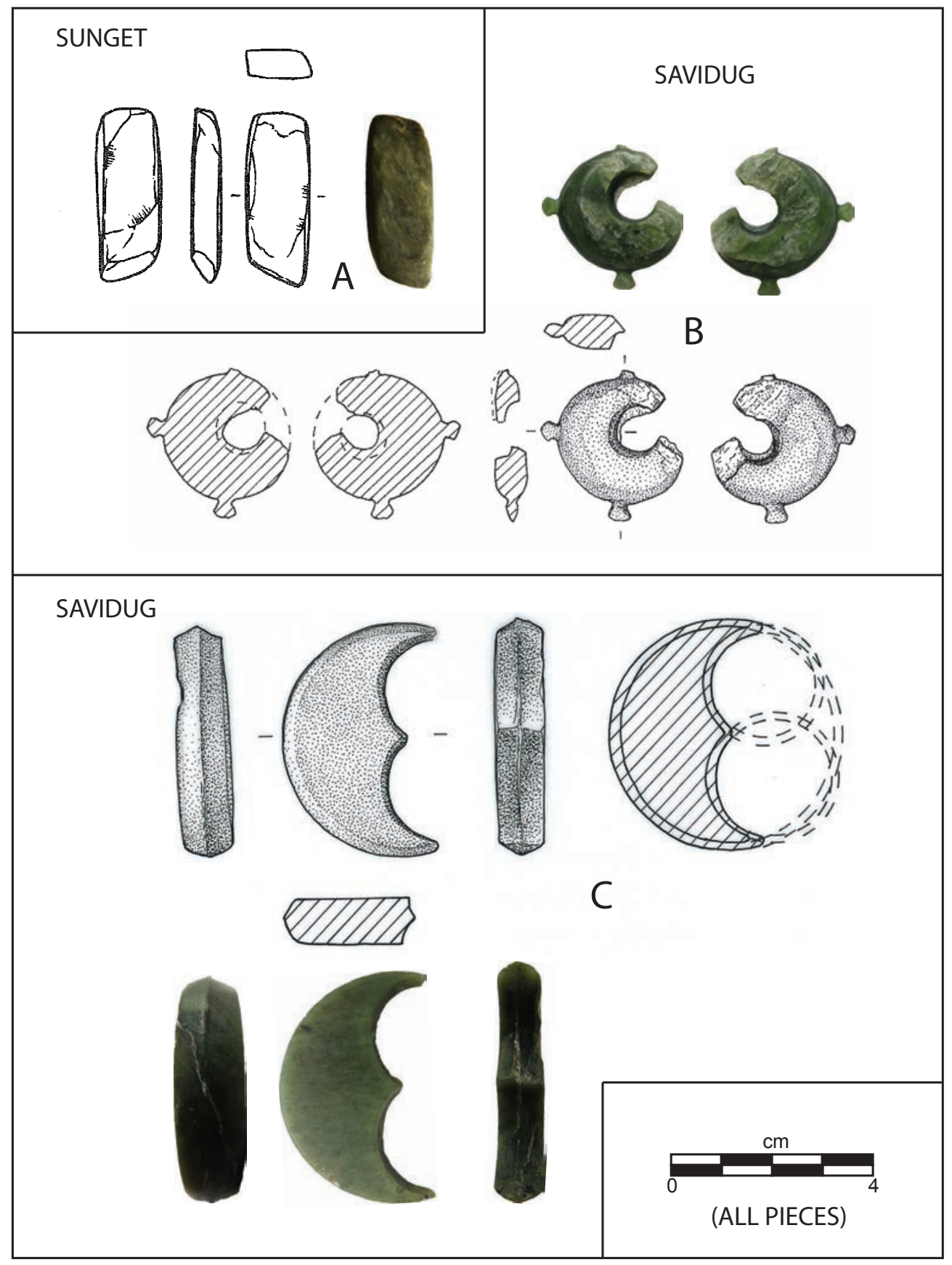

Figure 9.2. (A) Nephrite adze from Sunget. (B and C) Three-pointed lingling-o and pelta-shaped nephrite segment from Savidug (NB: the term pelta, used in European archaeology, refers to an object shaped like an ancient Greek light shield). Source: Hsiao-chun Hung. 

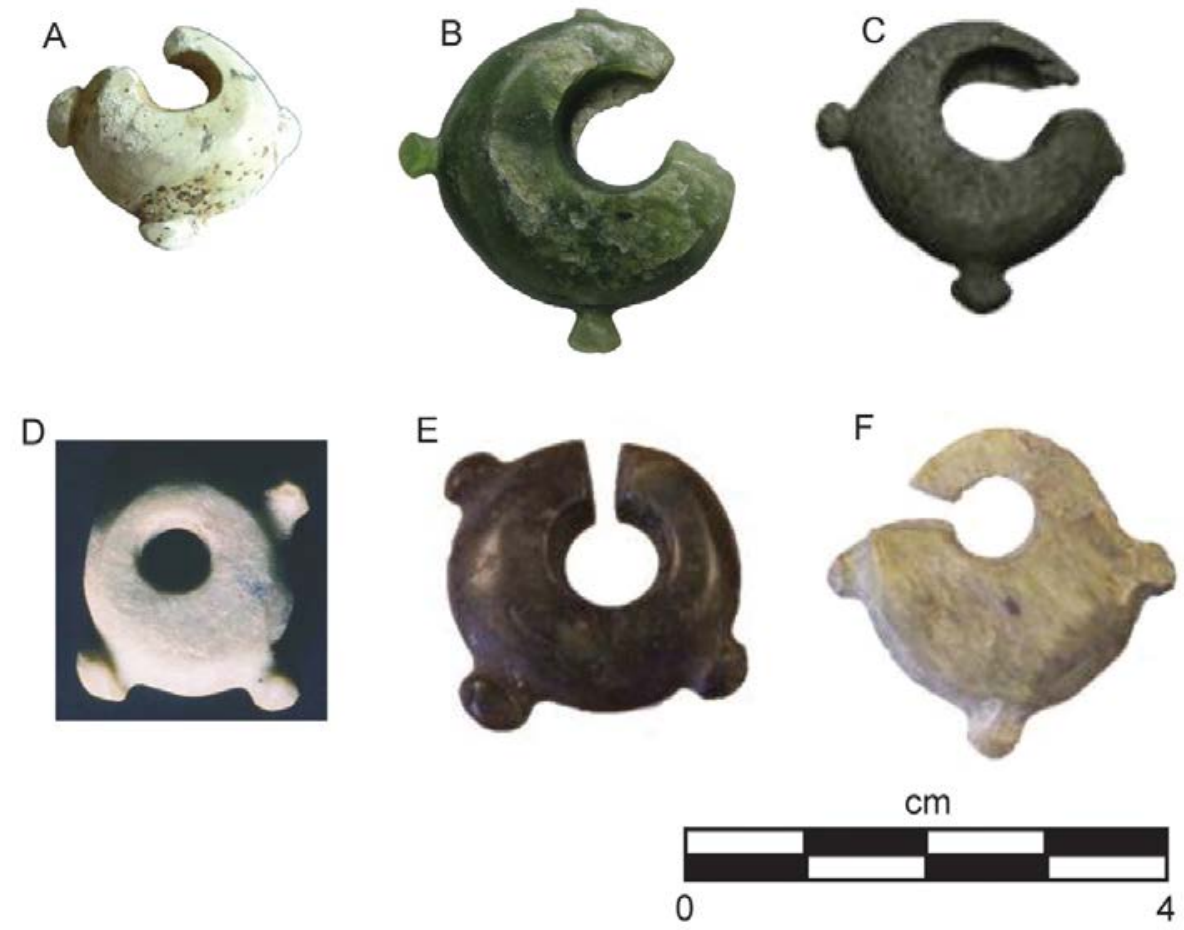

Figure 9.3. Possible nephrite prototypes for the lingling-o type of penannular earring with three pointed circumferential projections (see examples in Fig. 9.10), from:

(A) Hengchun, southern tip of Taiwan - courtesy National Museum of Prehistory, Taiwan;

(B) Savidug Dune Site, Sabtang (see also Fig. 9.2 B);

(C and D) Lanyu Island - courtesy National Museum of Prehistory, Taiwan;

(E and F) Arku Cave, Cagayan Valley - courtesy National Museum of the Philippines.

Source: Hsiao-chun Hung.

\section{Sabtang Island}

During the excavation of Savidug Dune Site, a Fengtian nephrite lingling-o with three rounded projections (Fig. 9.2 B) was found close to the base of a burial jar, in a layer dated to 590 to 390 BC (Wk 21809: Table 5.1). It is slightly different from the more numerous lingling-o earrings found in the Philippines which have three sharply-pointed projections (Fig. 9.10). As can be seen in Fig. 9.3, this Savidug specimen is paralleled by other examples from Hengchun in southern Taiwan (Hung and Bellwood 2010: Fig. 2.1), Lanyu Island (Hsu 2008: Fig. 34.9; Li 2010), and in nephrite and shell from Arku Cave in the Cagayan valley, northern Luzon (Thiel 1986-87: Fig. 5). The rounded knobs in these specimens are similar to those on the four-knobbed earrings of the Late Neolithic of Taiwan (see type IIA in the Beinan classification of Lien 2002). It is suggested here that they might have been ancestral to the lingling-os with more sharply-pointed projections from a wide range of sites in Taiwan, the Philippines, Sarawak, Vietnam, Thailand and Cambodia (Hung et al. 2007). Most of these sharply-pointed examples are of Iron Age date, and presumably younger than the $c .500 \mathrm{BC}$ date that might apply to the Savidug specimen discussed here.

The burial jar in Savidug trench QR/7-9, close to the base of which the lingling-o was found, had a red-slipped surface and its top had been intentionally removed (Figs 4.19, 4.20). Similar burial jars are very common in the Hualian region of eastern Taiwan, at sites such as Huagangshan 
and Yanliao, where nephrite production was also rather well developed. They belong to the

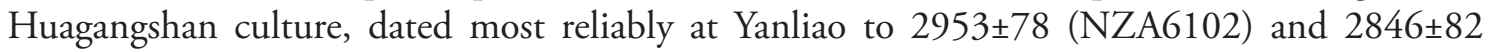
uncal. BP (NZA6101) (Ye 2001:96).

A pelta-shaped discard of Fengtian nephrite (Fig. 9.2 C) was also found in the Savidug road cutting, hence unstratified but quite probably from the same layer as the lingling-o. This had an original outer diameter of $4.9 \mathrm{~cm}$, and is $10 \mathrm{~mm}$ thick. The two drill-hole remnants have diameters very similar to that of the body (without the projections) of the Savidug lingling-o. We suspect that this pelta-shaped piece was debitage from lingling-o manufacture, since it is similar in shape to, but larger than, the specimens to be described below from Anaro and the site of Rusarsol on Lanyu Island (Hsu 2008: Fig. 34.1). Such pieces have never been found in other locations in Southeast Asia. Suggestions of how such pelta-shaped pieces, both large and small, could be produced by drilling out two discs offset from the diameter of an original circular blank of Fengtian nephrite are offered in Figs 9.2 and 9.7.

Within the same cultural layer at Savidug and from the same depth $(130-140 \mathrm{~cm})$ as the lingling-o, many double side-notched pebble sinkers of eastern Taiwan character were also found (Fig. 8.9, lower). All this evidence strongly suggests that the inhabitants of Savidug Dune Site had strong cultural relations with Taiwan, possibly with the Huagangshan sites around the mouth of the Hualian River in eastern Taiwan, and also with Lanyu Island. Some Huagangshan sites, such as Yanliao, have yielded large amounts of worked nephrite, associated with slate knives (Ye 2001).

\section{Itbayat Island}

Nine nephrite adzes were recovered as surface finds at Anaro (Fig. 9.4), of which at least five narrow specimens might be considered as chisels. Most have quite sharply rectangular crosssections, unlike the Anaro trapezoidal-sectioned adzes and circular-sectioned chisels of other raw materials described in chapter 8 . This rectangular-sectioned type of Taiwan nephrite adze/chisel was very common in the Middle (2500-1500 BC) and Late (1500-300 BC) Neolithic phases in Taiwan (Hung 2004), and some even continued to be used into the Iron Age. The largest Anaro nephrite specimen measures $7.1 \mathrm{~cm}$ in length, $4.9 \mathrm{~cm}$ in width, and $3.9 \mathrm{~cm}$ in thickness (Fig. 9.4, bottom left). Two parallel grooves occur on its surface, and we presume from this that some of the larger nephrite adzes taken to Anaro were eventually cut or drilled into smaller pieces and recycled for manufacturing ornaments.

The five fragmentary circular nephrite specimens from Anaro shown in Fig. 9.5 are from either half-finished or finished but broken ornaments, presumably rings, bracelets or earrings. Two of them (A and B) are from bracelet-like ornaments with off-centre perforations. Two others (D and $\mathrm{E})$ are small ring-shaped fragments presumably broken during manufacture, since the insides retain very clear drilling marks. The fifth perforated specimen (C) came from a finished ornament, but it is uncertain whether it was a bracelet or an earring.

In total, ten primary cores drilled out from the centres of circular ornaments were discovered from Anaro. Most were surface finds, except for two excavated from Anaro 3 at 65-70 cm (Fig. 9.6 A) and 70-75 cm (Fig. 9.6 D) respectively, They can be grouped into two types. Four (Fig. 9.6 A-D) are roughly conical or biconical in shape as a result of drilling from one or both sides of a thick blank. They are smaller in diameter than the second disc type to be described next. The two biconical specimens (A and $\mathrm{B}$ ) are both $0.8 \mathrm{~cm}$ in diameter, and we believe they were drilled from the central holes of the popular three-pointed type of lingling-o shown in Fig. 9.10, although none of these finished ornaments were actually found at Anaro, perhaps because all were exported for use elsewhere. 


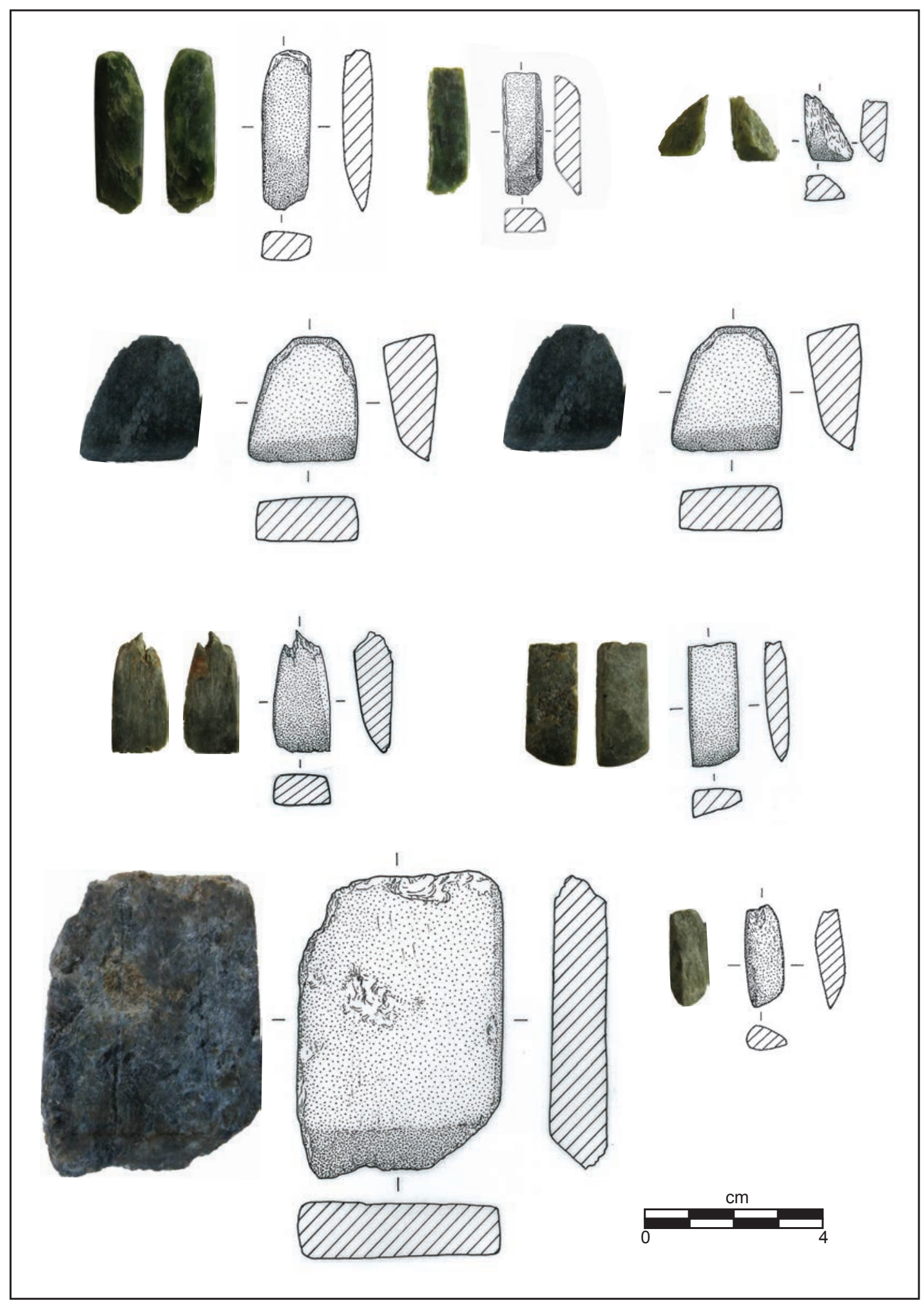

Figure 9.4. Nephrite adzes from Anaro.

Source: Hsiao-chun Hung. 


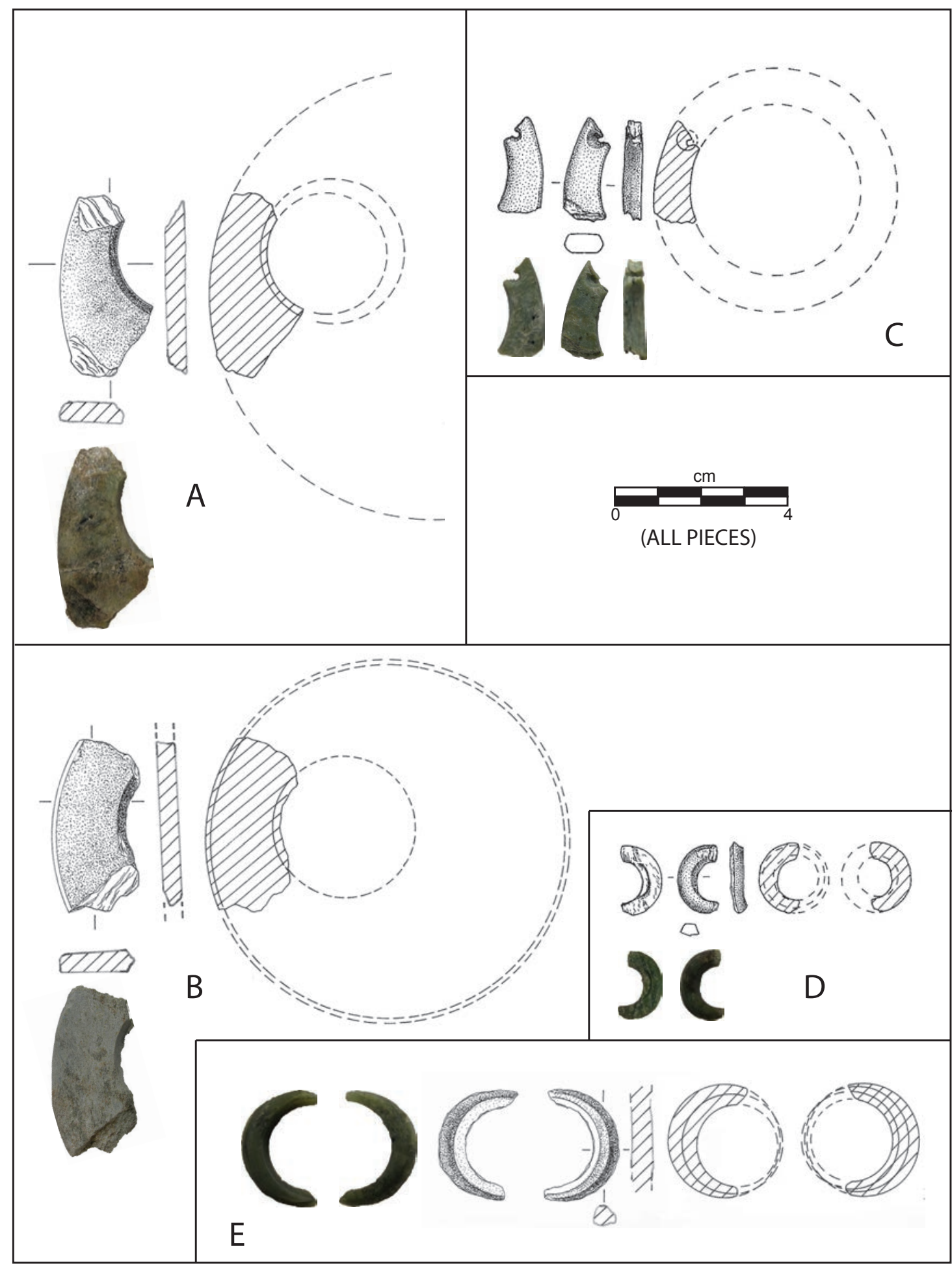

Figure 9.5. Fragments of circular ring-shaped nephrite ornaments from Anaro.

Source: Hsiao-chun Hung. 


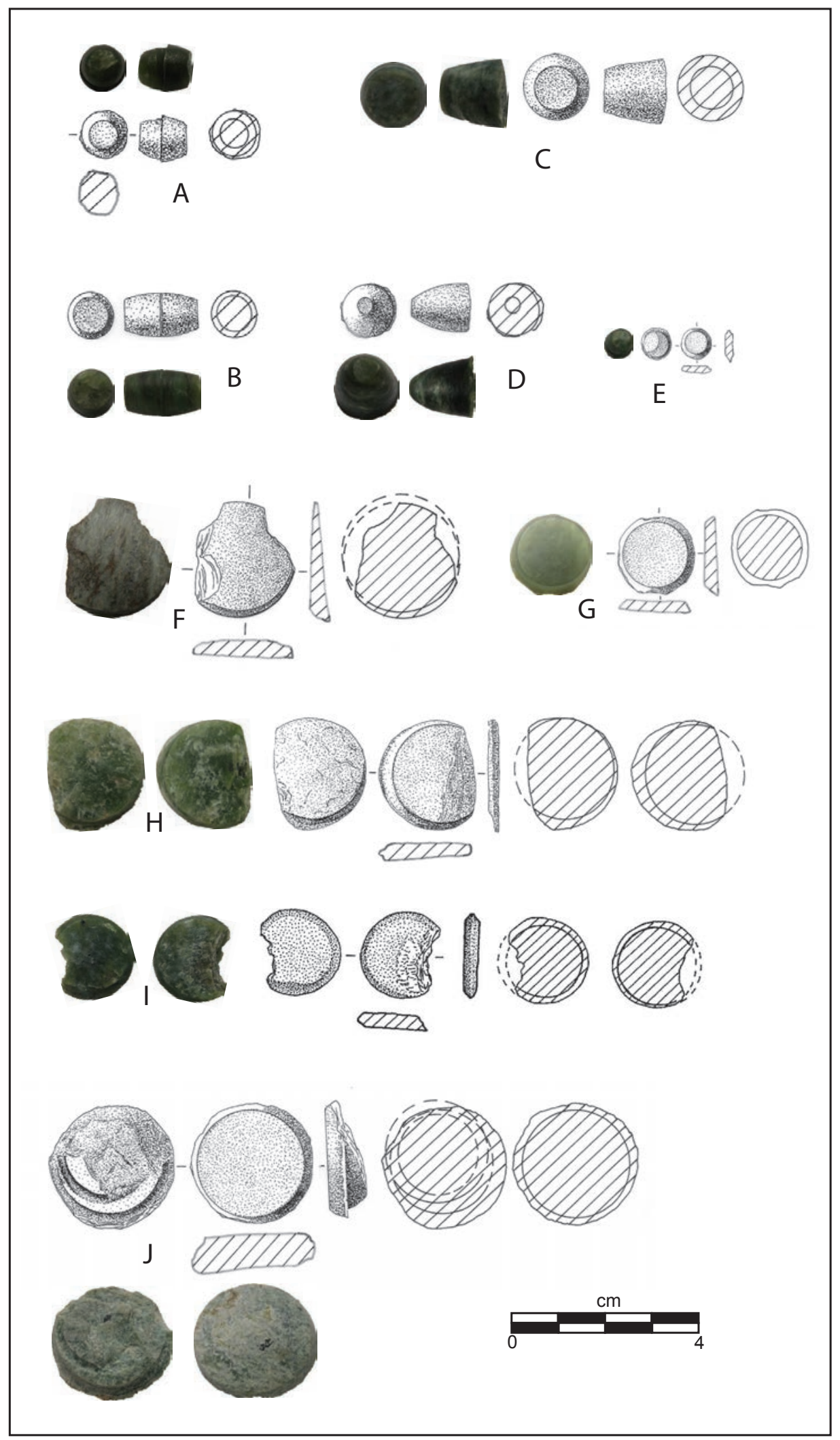

Figure 9.6. Drilled-out nephrite biconical and conical cores, and flat circular discs, from Anaro.

Source: Hsiao-chun Hung. 

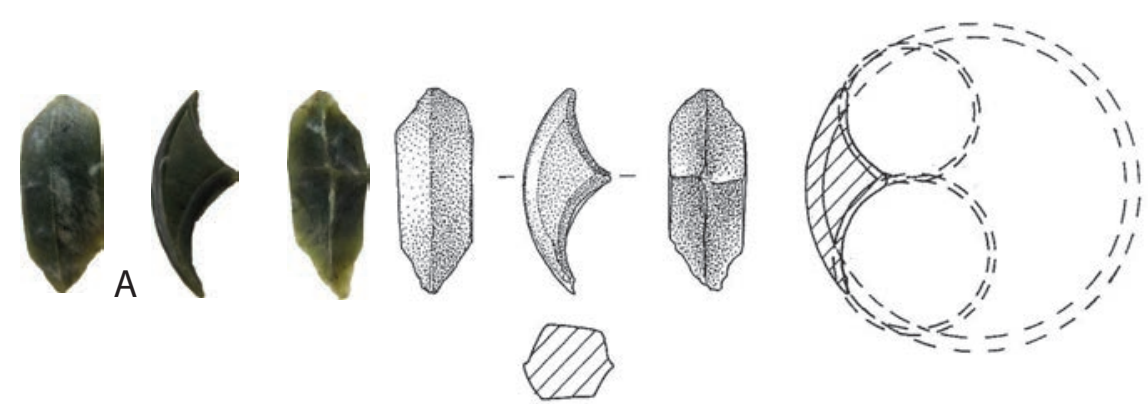

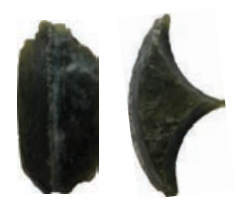

B
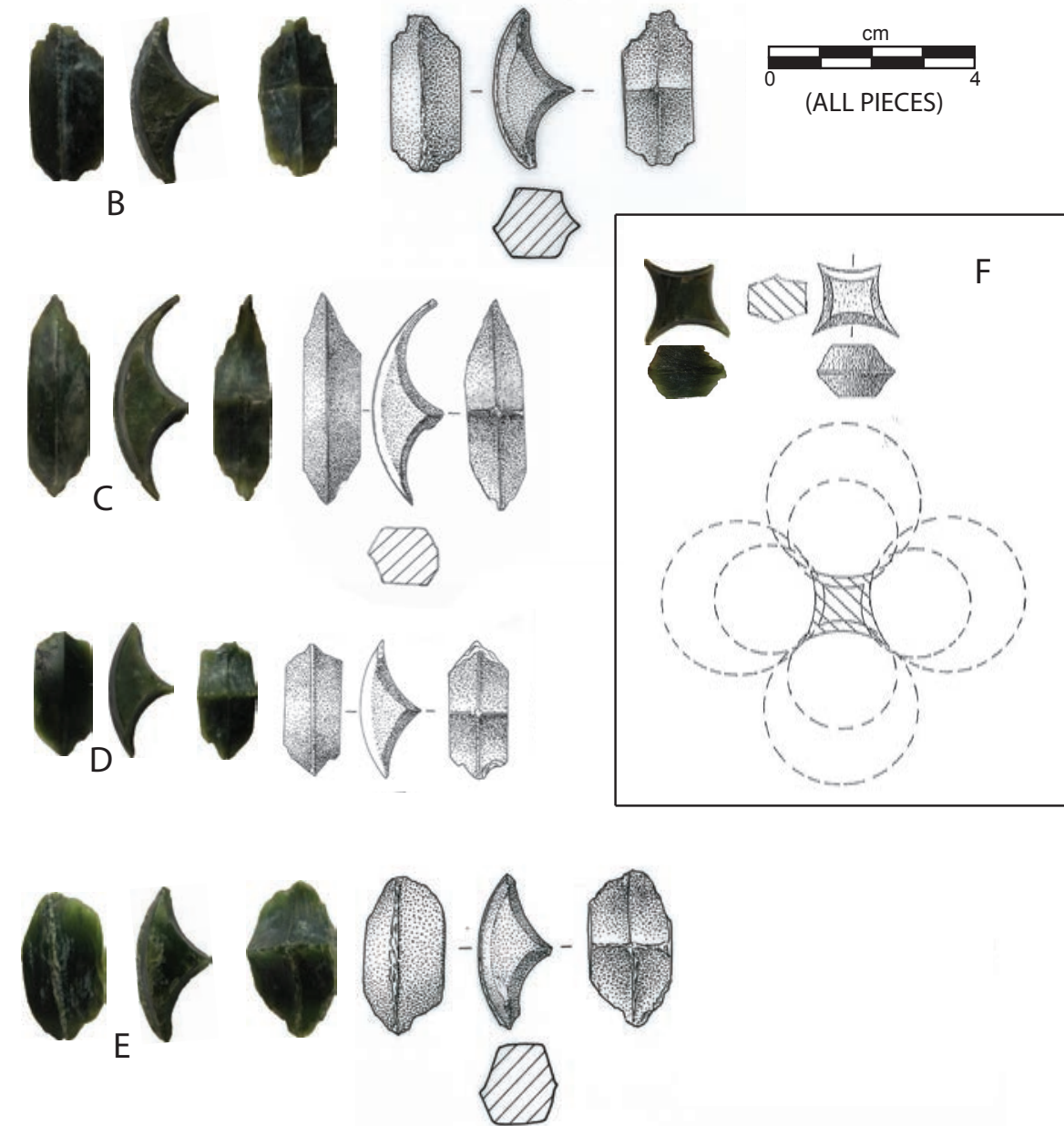

(ALL PIECES)
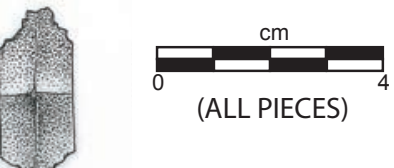


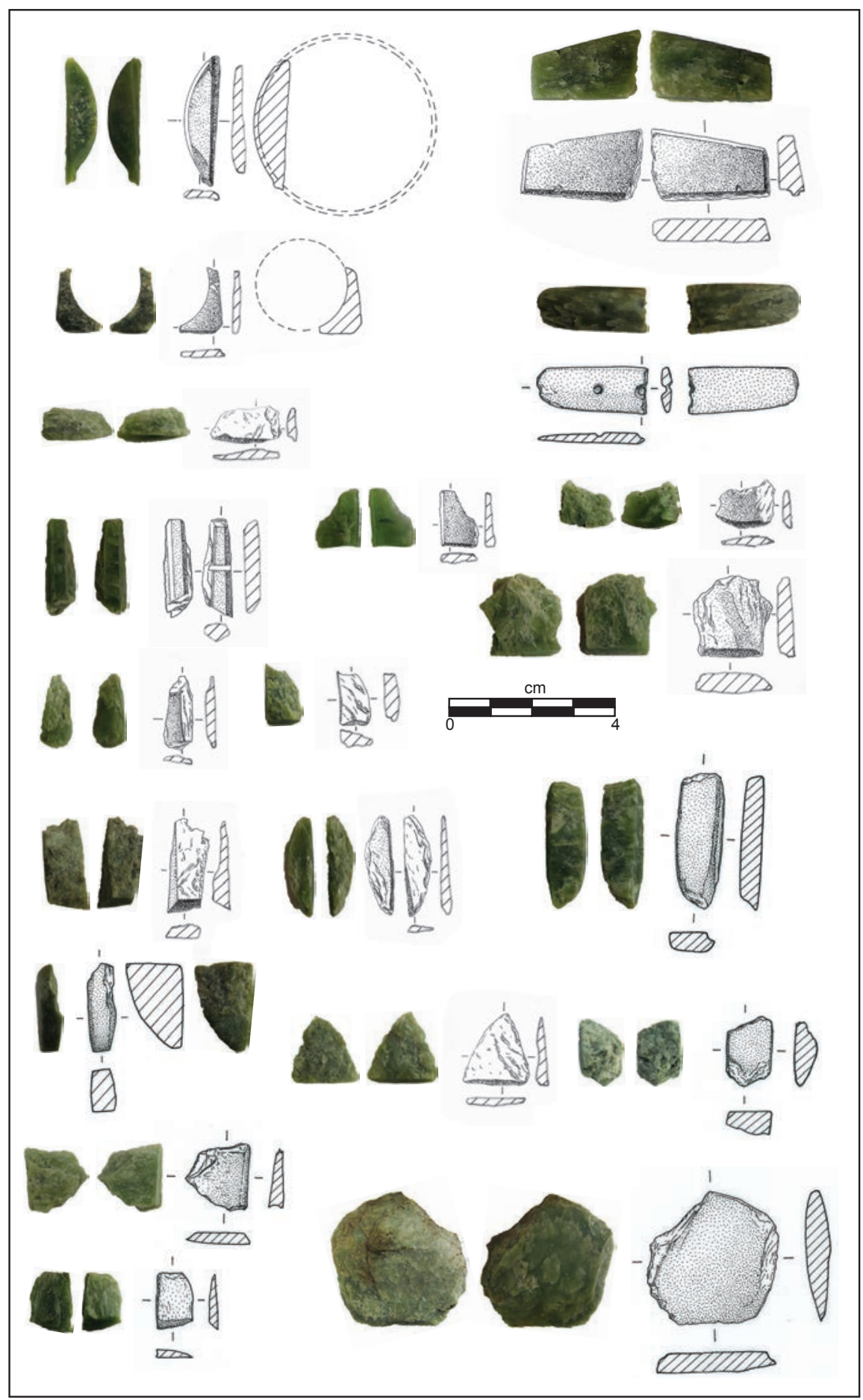

Figure 9.8. Other worked fragments of nephrite from Anaro.

Source: Hsiao-chun Hung.

Five pelta-shaped peripheral fragments resulting from double or quadripartite drilling into a large circular blank were found at Anaro (Fig. 9.7). These are similar to but smaller than the Savidug pelta-shaped specimen described above, and again one example of this precise form has been excavated at Rusarsol on Lanyu (Hsu 2008: Fig. 34.1 and 2). Four were surface finds, but that shown as Fig. 9.7 B was found at 10-15 cm in Anaro 5, a shallow square dug on the flat limestone top of the hill. The star-shaped specimen shown as Fig. $9.7 \mathrm{~F}$ is the only one of this shape found 
so far in Batanes, or elsewhere in Southeast Asia, and it appears to be the central remnant left after drilling out four circular cores from a large circular blank, with the pelta-shaped pieces coming from the outer periphery. We can observe clearly from the profiles of all of these specimens that they were drilled from both sides of their blanks, perhaps using bamboo bow drills and sand. The holes were originally hourglass-shaped in section.

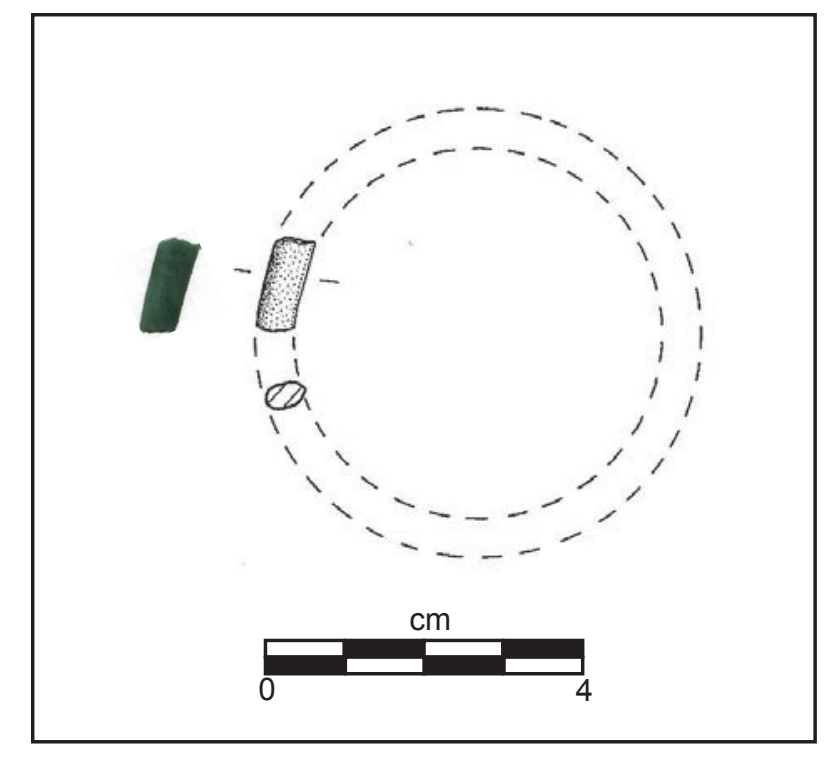

Figure 9.9. A fragment of a muscovite bracelet from Anaro.

Source: Hsia0-chun Hung.

In total, 20 other worked nephrite fragments of rectangular, curved or irregular shapes were also collected from Anaro (Fig. 9.8). Most grooves and drilling marks were made from both sides of the blanks, and in the case of grooving the usual procedure seems to have been to cut in from both sides until a thin ridge was left, which could be snapped prior to polishing and finishing.

Anaro is the most important nephrite workshop found so far in the Philippines, as it illustrates what appears to be the full production sequence for making circular rings and ear ornaments, including possibly the widespread type of lingling-o with three projections (Hung et al. 2007). Many slate pieces, probably used as knives since many were formed from broken projectile points, were also found here with the nephrite fragments (Fig. 8.8). We suggest they were used with sand and water for grooving the nephrite prior to snapping, as in the nephrite workshops at Pinglin, near the Fengtian nephrite source, in Taiwan. As mentioned, these slate tools were imported to Batanes from Taiwan, where such knives and points are very common.

Beside nephrite materials, one green muscovite fragment, cylindrical in cross-section, was also found on the surface at Anaro (Fig. 9.9). It probably came from a broken bracelet or ear pendant. This muscovite is called "Mindoro jade" in the Philippines and is smooth and greenish in colour (Hung et al. 2005), not as hard as nephrite, and of a paler green. A number of jade-like lingling-o earrings and beads in the Philippines were manufactured of this material (see below for further discussion).

\section{The Batanes green nephrite and muscovite artefacts in the context of Philippine and Southeast Asian archaeology}

After examining the specimens of nephrite and similar raw materials in the collections of the Philippine National Museum, we suggest that several types of raw material, namely green nephrite, 
white nephrite, green Mindoro muscovite, and other greenish raw materials (such as green quartz schist, talc and steatite) were used to manufacture stone ornaments during the Neolithic and Iron Age of the Philippines.

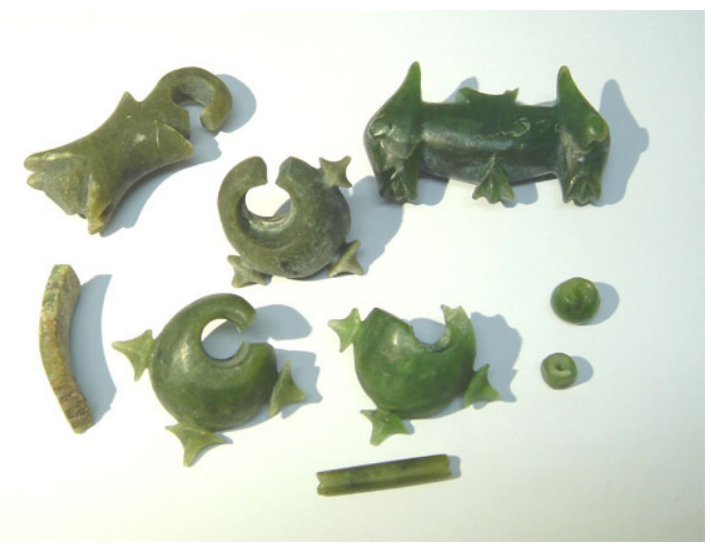

Figure 9.10. Green nephrite lingling-os and double animal-headed ear pendants from the Tabon Caves, Palawan.

Source: Hsiao-chun Hung.

Most of the green nephrite artefacts examined in the Philippines (including those from Batanes) are translucent green in colour, with black inclusions. All specimens tested by Yoshiyuki lizuka are of Fengtian nephrite, and most were manufactured by sawing, drilling and polishing to produce body ornaments such as beads, bracelets, and double animal-headed and lingling-o earrings (Fig. 9.10). Very few adzes of green nephrite occur in the Philippines, except in the Batanes Islands. So far, more than 400 green nephrite ornaments have been discovered in the Philippines, at about 20 different sites (Fox 1970: 135; Hung 2005, 2006) including the following (Fig. 9.11):

1. Anaro, Sunget and Savidug in Batanes, as described here;

2. Nagsabaran, Lanna, Arku Cave and Lattu-Lattuc Cave in the Cagayan Valley, northern Luzon (Barbosa 1979);

3. Dimolit in Isabela, northeastern Luzon;

4. Calatagan and Kay Daing in Batangas, western Luzon;

5. Bato Cave in Sorsogon, southern Luzon;

6. Kalanay Cave on Masbate Island;

7. Leta-Leta and Ille Caves in northern Palawan;

8. Duyong, Manunggul, Uyaw, Guri, Bubulungun and Rito-Fabian Caves (all within the Tabon Caves complex) central Palawan.

According to our previous studies, all examined Taiwan nephrite artefacts, and the Fengtian geological source rocks themselves, are composed of nephrite (tremolite-actinolite amphiboles) with zinc-bearing chromite inclusions. The results suggest that Fengtian was the major source for all of the nephrite artefacts so far analysed from Taiwan itself. Outside Taiwan, more than 100 artefacts from more than 10 sites in Southeast Asia have been confirmed by Yoshiyuki Iizuka as made of Fengtian nephrite. These sites occur in the Batanes Islands, Luzon, Palawan, Sarawak, central Vietnam, southern Vietnam and southern Thailand (Iizuka et al. 2006; Hung et al. 2007). No Fengtian nephrite has yet been reported from northern Vietnam. 


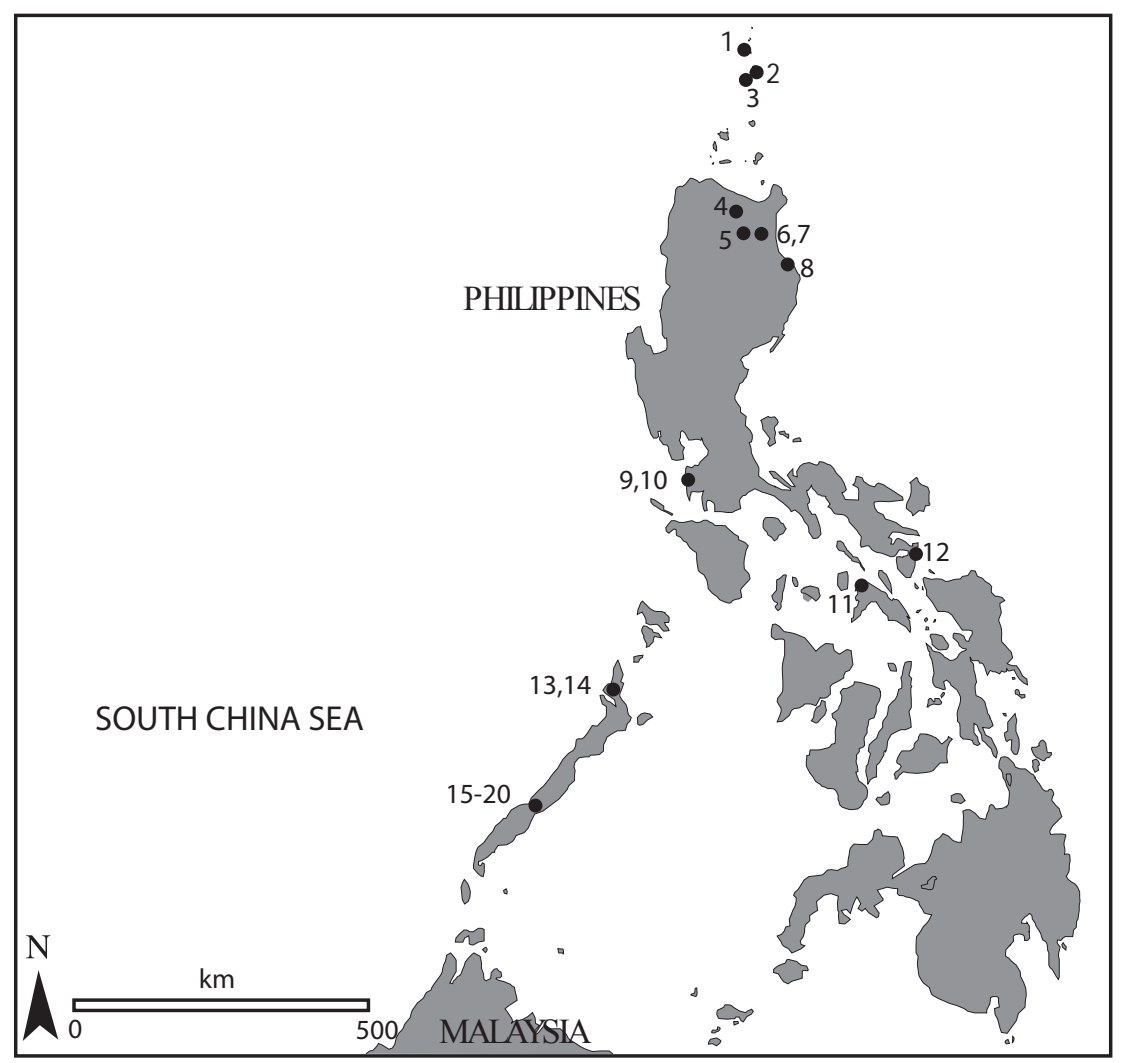

Figure 9.11. The distribution of green nephrite ornaments in the Philippines. 1. Anaro; 2. Sunget; 3. Savidug; 4. Nagsabaran, Cagayan Valley; 5. Lanna, Cagayan Valley; 6. Arku Cave, Cagayan; 7. Lattu-Lattuc Cave, Cagayan; 8. Dimolit, Isabela; 9-10. Calatagan and Kay Daing, Batangas; 11. Kalanay Cave, Masbate Island; 12. Bato Cave, Sorsogon; 13-14. Leta-Leta and Ille Caves, northern Palawan; 15-20. Duyong, Manunggul, Uyaw, Guri, Bubulungun and Rito-Fabian Caves, central Palawan.

Source: Hsiao-chun Hung and Mike Carson.

In addition to the numerous artefacts of Fengtian nephrite found in the Philippines, a single adze blade fragment with an exceptional green colour was found in 1994 by Armand Mijares in Tinokod Cave, Abra de Ilog, Occidental Mindoro (Mijares 1996: 33). The adze had been manufactured by flaking and polishing into a quadrangular shape with a trapezoidal cross-section. Its matrix component is actinolite/tremolite amphibole, consistent with nephrite of a chemical composition comparable to Fengtian nephrite. However, the inclusion minerals of this piece are different. Therefore, it was not derived from Fengtian, and its source remains unknown.

\section{White nephrite adzes in Luzon}

Philippine white nephrite artefacts (Figs 9.12 and 9.13) are usually milky on the surface, sometimes with reddish-brown, black or green bands. Almost all were manufactured by flaking and polishing into adzes with trapezoidal cross-sections, including some that were stepped for hafting. So far, we have seen only adzes, axes, chisels and gouges in this white nephrite, and have not encountered any ornaments made of this material (Hung et al. 2005). Although a large number of white nephrite adzes and similar tools were collected by Beyer in the 1930s and 1940s in southern Luzon, he left insufficient information about the contexts of the finds. The sites of Beyer's primary explorations were in Bulacan, Rizal, Laguna, Batangas and Quezon provinces. In the past decade, more white nephrite adzes have been found in the Baha and Ulilang Bundok 
open sites in Calatagan (de la Torre 2003), at Ille Rockshelter in northern Palawan, and possibly on Siargao Island in Surigao del Norte, eastern Mindanao (Cecilio Salcedo, National Museum Manila, pers. comm.). None have ever been found in Batanes. Although the exact number of white nephrite adzes found by Beyer is unknown, his publications (Beyer 1947, 1948) and the National Museum of the Philippines collections indicate that several thousand were discovered in southern Luzon, a quantity much greater than the total of green nephrite artefacts found in the Philippines.

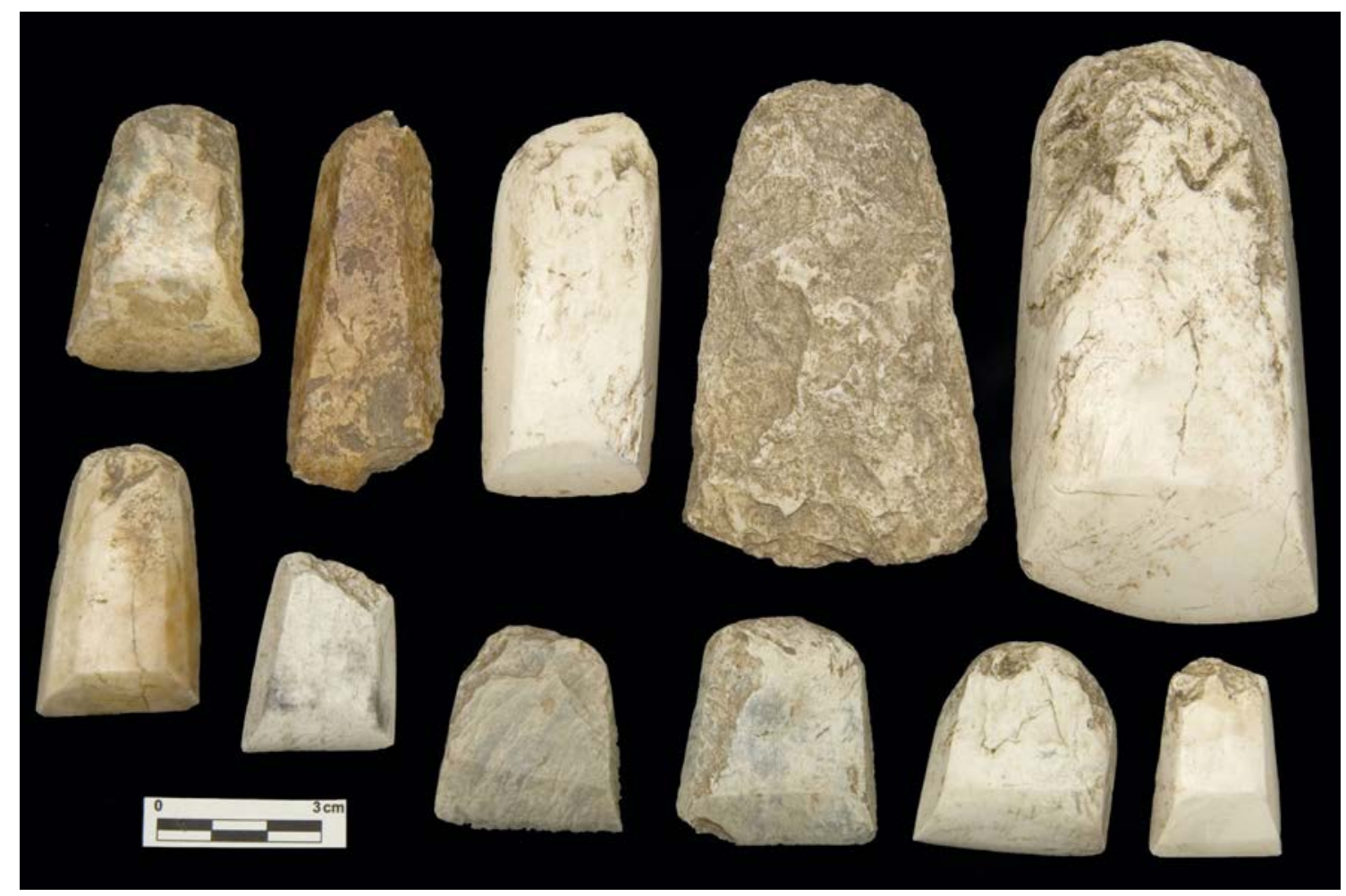

Figure 9.12. Examples of white nephrite adzes from the Philippines (Beyer collection, courtesy: National Museum of the Philippines).

Source: Hsia0-chun Hung.

Mineralogical and geochemical analyses of 15 white nephrite adzes and two preforms from the Beyer collection, and one adze from Ulilang Bundok, show that the raw materials are tremolitic amphibole, or tremolite. Their chemical compositions clearly differ from the green (actinolite) nephrites, such as that from the Fengtian source (Iizuka and Hung 2005). The oxygen isotope ratios of the white nephrite adzes are the highest of all known tremolite sources in East Asia (Iizuka and Hung 2005; Hung et al. 2005; Hung et al. 2007), and given the large numbers in southern Luzon and their apparent absence in Batanes, it is likely that the raw material came from somewhere in southern Luzon, perhaps from a geological zone where marble and/or muscovite occur. However, this source so far has not been found.

\section{Green Mindoro muscovite, or "Mindoro jade"}

This raw material was also used for making earrings and beads in the Philippines. A Neolithic example of a "Mindoro jade" earring was found with red-slipped pottery at Irigayen in the Cagayan Valley (de la Torre 2000: 128); this specimen curiously mimics a style of earring common at Beinan (Late Neolithic of eastern Taiwan, c.1500-300 BC). It has been tested by Yoshiyuki Iizuka and confirmed as highly similar in composition to Mindoro muscovite. Several other ornaments 
from Calatagan in Batangas, such as two disc beads from Ulilang Bundok (Fig. 9.14), and four disc beads from Ngipe't Duldug cave on Palawan, all green in colour, were also found to be made of this kind of muscovite.

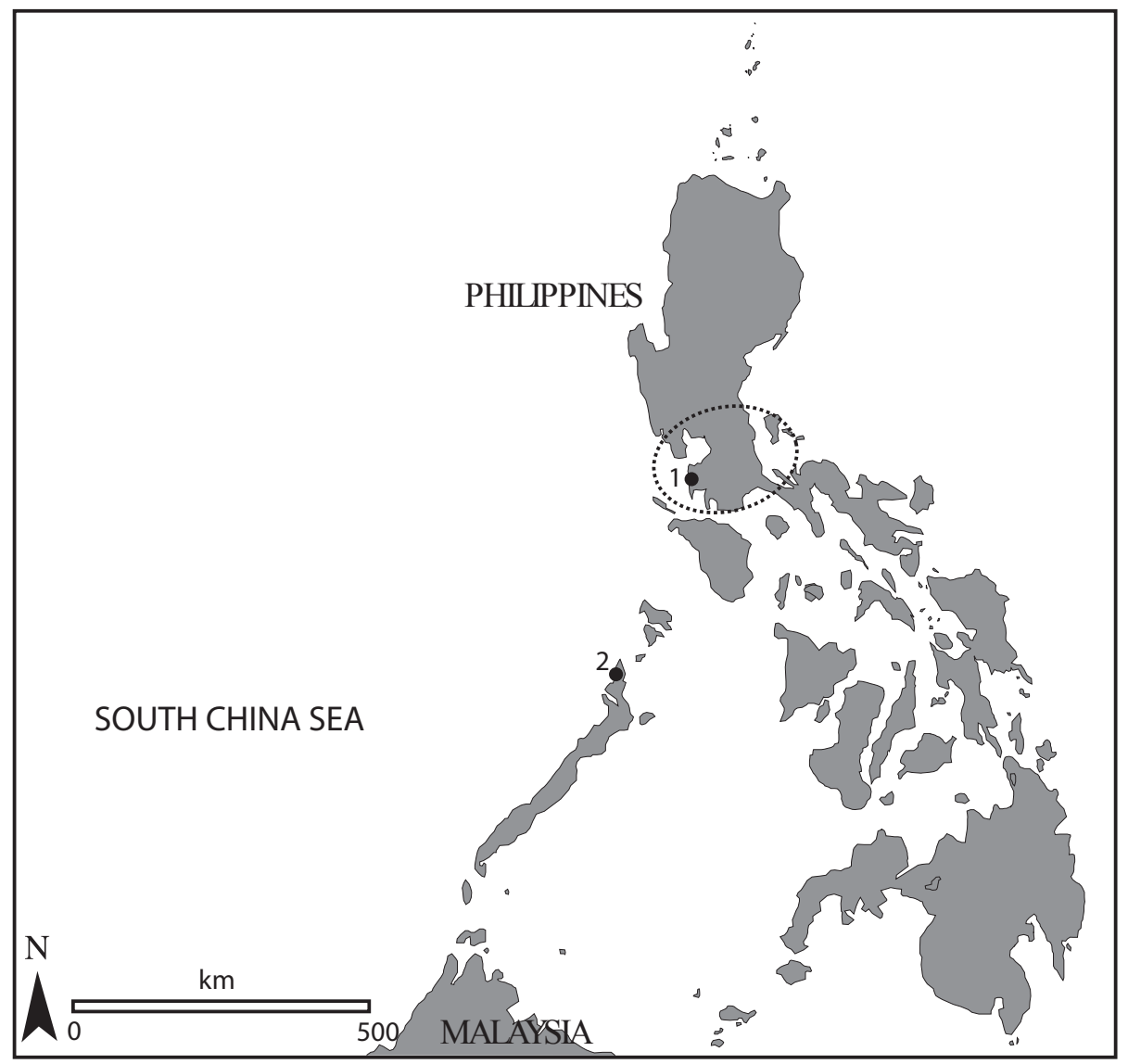

Figure 9.13. The distribution of white nephrite adzes in the Philippines; the shading marks the primary region of Beyer's discoveries in central Luzon. 1. Baha and Ulilang Bundok, Calatagan, Batangas; 2. Ille Cave, El Nido, northern Palawan.

Source: Hsiao-chun Hung and Mike Carson.

In July 2005, Hsiao-chun Hung examined a number of nephrite artefacts in private collections in Manila. Several ornaments in the collections of Richard Lopez and Ramon Villegas appeared to be made of Mindoro jade, including 14 lingling-o earrings with three pointed projections and 7 cylindrical beads. Based on these, and other observations, most Mindoro jade artefacts have apparently been found in Cagayan, Batangas and Palawan (Fig. 9.15), together with the muscovite bracelet fragment (Fig. 9.9) discovered at Anaro and mentioned above. Presumably, ancient people sometimes selected this material as a local substitute for green nephrite.

One of the known sources of muscovite is located at Arakaak, Santa Cruz, Mindoro Occidental (Mary Jane Bolunia and Rey Santiago, National Museum of the Philippines, pers. comm.). We cannot be certain that this type of muscovite occurs only in Mindoro, but we are unaware of any other source in the Philippines. From our analyses, the geological raw material from Arakaak, and the ornaments from Irigayen, Calatagan and Ngipe't Duldug Cave, have all been confirmed as muscovite of the Mindoro type (Hung et al. 2005). At present, it is likely that Mindoro Island was the source for these muscovite ornaments, but this material is more difficult to source with precision than nephrite. 


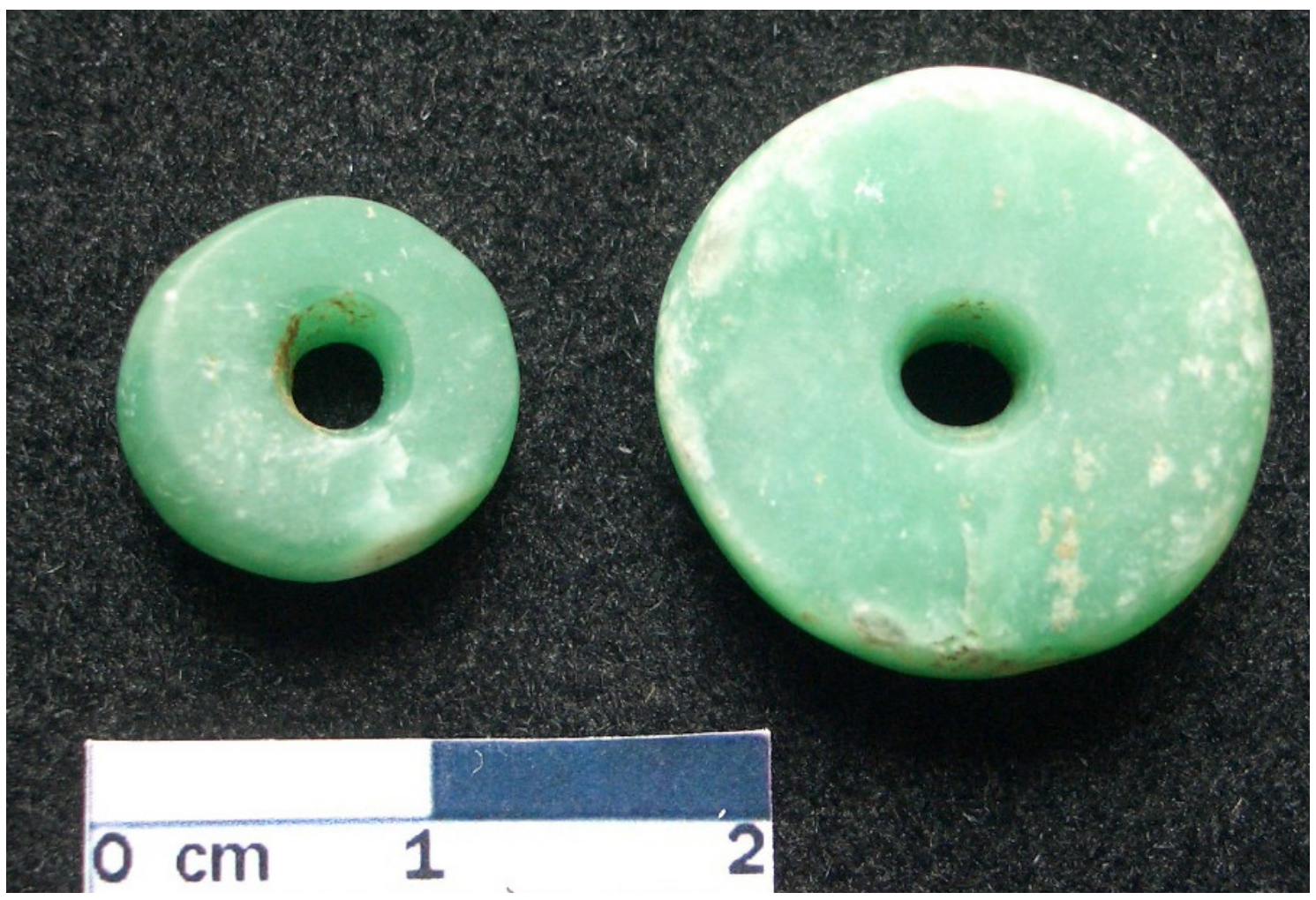

Figure 9.14. "Mindoro jade” (muscovite) disc beads from Ulilang Bundok, southern Luzon, excavated by Amalia de la Torre. Courtesy: National Museum of the Philippines.

Source: Hsia0-chun Hung.

Elsewhere in Island Southeast Asia, a perforated pendant of probable Mindoro jade has been discovered in a Neolithic context at Bukit Tengkorak in Sabah, dated to c.1300 BC (Peter Molijol, Sabah Museum, pers. comm. to Peter Bellwood). This piece has been analysed by lizuka and confirmed as the same muscovite raw material. However, no Fengtian nephrite has ever been found in Sabah. Muscovite artefacts have been found in other parts of Southeast Asia (but not yet in Taiwan), often co-occurring with objects made of Fengtian Taiwan nephrite, as in Guri Cave on Palawan, and in coastal Vietnam and Peninsular Thailand. Therefore, we suspect that the muscovite was traded through the same networks as the Fengtian nephrite.

\section{Green quartz schist}

Quartz schist, talc and shell were also shaped by drilling, sawing and polishing into beads, bracelets and earrings in the Philippines. These artefacts exhibit strong similarities with the green nephrite ornaments, in terms of both manufacturing technology and style. The green quartz schist was used specifically for making disc-shaped beads, found in more than 10 Philippine sites. Most are either fresh green on the surface and similar to green nephrite in colour, or weathered grey. Their distribution in the Philippines is very wide, including northern and southern Luzon and Palawan, but not yet Batanes. 


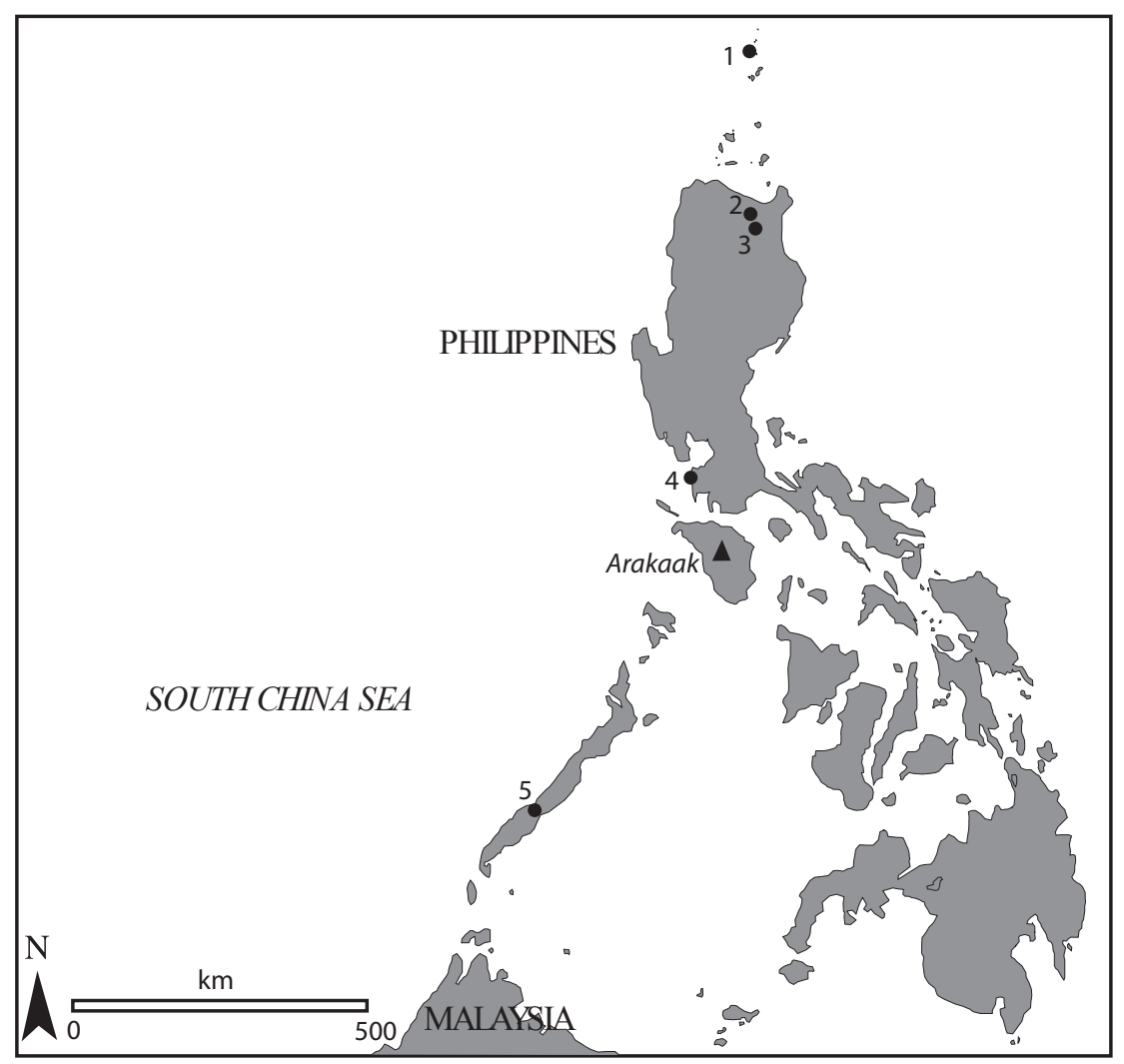

Figure 9.15. The distribution of "Mindoro jade" (muscovite) ornaments in the Philippines; 1. Anaro, Itbayat Island; 2. Irigayen, Cagayan Valley; 3. Magapit, Cagayan Valley; 4. Ulilang Bundok, Calatagan, Batangas; 5. Ngipe't Duldug cave, Quezon, Palawan. The triangle marks the possible Mindoro jade (muscovite) source at Arakaak on Mindoro.

Source: Hsiao-chun Hung and Mike Carson.

Geologically, green quartz schist is common in metamorphic regions. Although we have not yet been able to trace the source of the raw material, southern Luzon is a potential area because so many quartz schist beads have been found there. They show a high level of standardization, implying specialized production (Hung 2008: 178-179).

\section{Nephrite workshops in Taiwan, and on Ludao and Lanyu Islands}

In Taiwan, workshop sites utilising Fengtian nephrite have been discovered at Pinglin, Chongguang and Yanliao, all in Hualian Province in eastern Taiwan and close to the Fengtian source (see Fig. 1.1 for locations). Offshore, they have been found at Youzihu on Ludao Island, and at Rusarsol (Lanyu High School) on Lanyu Island. Tested nephrite artefacts from Guanyindong on Ludao $(\mathrm{n}=4)$ and Rusarsol on Lanyu $(\mathrm{n}=5)$ have all been confirmed as Fengtian nephrite. Outside the Philippines, worked Fengtian nephrite has been found at Giong Ca Vo on the coast of southern Vietnam near Ho Chi Minh City (Dang et al. 1998), and at Khao Sam Kaeo in southern Thailand (Hung et al. 2007: 19749).

On Ludao, the Youzihu site was first excavated in 1929 by Tadao Kano (1946), who collected a green nephrite bracelet with incised crossed line decoration similar to one found in the Tabon Caves, two drilled-out nephrite discs $4-5 \mathrm{~cm}$ in diameter and $1.5 \mathrm{~cm}$ thick, long beads, pendants, and several types of lingling-o earring. The latter included lingling-o with four pigeon-tail projections and hook-shaped forms (Kano 1942). According to the quantity of drilled-out discs from Youzihu, this site probably served as a nephrite workshop, but at an uncertain date. The site 
has produced red-slipped pottery with circle-stamping like that made in Batanes Phase 2, and a shell "spoon" like that from Savidug Dune Site (Fig. 8.14 D), supporting a date during the first millennium BC. Other artefacts from Youzihu (Liu et al. 1995) indicate a date possibly prior to 1000 BC, contemporary with the Late Neolithic Beinan cultural phase in southeastern Taiwan, but the relevance of this for dating the nephrite remains uncertain.

Kano (1946) also described several types of nephrite earring from Lanyu, including a lingling-o with three projections, two lingling-os with four pigeon-tail projections, and simple penannular rings. He noticed that some small discs from Lanyu, like those from Anaro (Fig. 9.6 E-J), were less than $2 \mathrm{~cm}$ in diameter and about $0.4 \mathrm{~cm}$ thick. In 1980, nephrite lingling-os with three or four pigeon-tail or knuckle-shaped projections, nephrite bracelets, grooved nephrite debris and many drilled-out cores were found in association with jar burials and glass beads at Rusarsol (Lanyu High School). In addition, several house owners in this area found nephrite ornaments during property construction in 1997-1998, including two bracelets and one more lingling-o with four knuckle-shaped projections. In typology and size, most of the Lanyu lingling-os are similar to those from Philippine Iron Age contexts, such as those from Arku Cave in northern Luzon and the Tabon Caves in Palawan.

Hsu's $(2003,2008)$ findings at Rusarsol are particularly important. She reported 19 nephrite specimens from there, including a pelta-shaped segment identical to the five from Anaro (Fig. 9.7 A-E), small secondary drilled-out cores like those in Fig. 9.6 E-J, and unfinished three-pointed lingling-os. This worked nephrite assemblage has some remarkable similarities to that from Anaro, and both sites were clearly in direct communication and involved in the manufacture of similar types of ornament.

Although a radiocarbon date of $1200 \pm 40 \mathrm{BP}$ comes from one of the Rusarsol jar burials (Tsang 2005), and Hsu (2008) accepted this age for the workshop, we argue that the date of the nephrite assemblage is earlier than 1200 years ago, given the much older date range for lingling-os in the Philippines and Vietnam (Hung et al. 2007). Rusarsol also has pottery with circle stamping similar to the Anaro circle-stamped type 1 pottery from Itbayat, dated between $500 \mathrm{BC}$ and $\mathrm{AD} 1$.

According to the general similarities between Lanyu and the Batanes in pottery decoration, nephrite ornaments and jar burial practices (de Beauclair 1972; Bellwood and Dizon 2005, Hsu 2008), we suggest that the Neolithic and especially the Early Iron Age inhabitants of these islands shared close contacts, and probably created new fashions in nephrite artefacts, such as the lingling-o earrings, different from the shapes most favoured on the Taiwan mainland.

\section{Conclusions}

In Southeast Asia, the most numerous and geographically widespread penannular nephrite earrings of lingling-o type have three pointed circumferential projections (Fig. 9.10). They occur in southern Taiwan, the Philippines, Borneo, southern Vietnam and southern Thailand, and are mostly dated between $500 \mathrm{BC}$ and AD 1. Both Anaro and Rusarsol yielded small disc-shaped drilled-out cores and pelta-shaped segments, and Anaro also yielded conical and biconical drilledout cores. All of these items seem to have resulted from the manufacture of annular rings or penannular earrings, including possibly those of the lingling-o type with projections. The specific pelta and star shapes in nephrite are not known from other workshops outside Batanes and Lanyu.

We suspect that one likely prototype lingling-o had three rounded rather than pointed projections, like the specimen from Savidug, dated to $c .600-400$ BC (Fig. 9.2 B; Fig. 9.3). As noted, similar 
specimens have been found in southern Taiwan, Lanyu and the Cagayan Valley, and the rounded rather than pointed projections on all of them find parallels in earrings from Beinan Late Neolithic contexts in southeastern Taiwan.

Regardless of the Late Neolithic and Iron Age manufacture of nephrite ornaments in Lanyu and Batanes, we must remember that Fengtian nephrite was utilised as early as $3000 \mathrm{BC}$ in Taiwan itself. It was already being exported outside Taiwan by 2000-1500 BC, as shown by two nephrite bracelet fragments found in the lower deposits with circle and punctate stamped redslipped pottery at Nagsabaran in the Cagayan Valley (Hung 2008; Hung et al. 2011). The oldest Fengtian nephrite in Batanes could be as early as 1200 BC, from Sunget and Anaro, but apart from adzes it is not clear what other kinds of artefact were in use at this time, or if nephrite was actually worked in Batanes then.

We might ask finally why Fengtian nephrite workshops were located on small and rather inhospitable islands such as Lanyu and Itbayat? These islands have little land suitable for intensive agriculture and neither supported very much rice growing in prehistory, or even now, although Lanyu does support extensive areas of wet taro cultivation today (Kano 1952). Therefore, it seems likely that the boat technology that these islanders must have relied upon for survival in prehistory was a crucial element behind the nephrite working tradition, since it would have enabled them to reach the desired sources of nephrite in eastern Taiwan, and to travel back home with the raw materials afterwards. Thus, the inhabitants of Lanyu and Itbayat were seemingly importing raw materials, and exporting finished nephrite goods. What they received in return for the latter remains unclear, but perhaps we can imagine other scarce subsistence and technological resources such as the animal hides and iron referred to by Dampier (see page 6).

One major question remains. How did the Lanyu and Itbayat workshops interact and communicate, if at all, with the other nephrite workshops identified in southern Luzon, central and southern Vietnam, and southern Thailand? The nephrite itself certainly travelled far. But did the artisans? 